\title{
ARTICLES
}

\section{BREAST CANCER AMONG FEMALE - A REVIEW}

\author{
Ms. Navjot Kaur* | Dr. Ramesh Kumari** \\ * Ph.D. scholar at Himalayan University at Itanagar, Arunachal Pradesh, India. \\ ** Research Guide, Himalayan University at Itanagar, Arunachal Pradesh, India. \\ DOI: http://doi.org/10.47211/trr.2019.v05i02.009 \\ Received $20^{\text {th }}$ October 2019, Accepted $6^{\text {th }}$ December 2019, Published $20^{\text {th }}$ December 2019
}

\begin{abstract}
Cancer is a group of diseases in which cells in the body grow, change and multiply out of control. Breast cancer is among the commonest of all human cancers throughout the world. Breast cancer is an uncontrolled growth of breast cells. There is no single specific cause of breast cancer; rather a combination of hormonal, genetic and possibly environmental events may contribute to its development. Cancer is a group of diseases in which cells in the body grow, change and multiply out of control. Genetic mutations, increased age, null parity, early menarche, late menopause, exposure to ionizing radiations, obesity, family history of breast cancer, hormonal replacement therapy, alcohol intake are some of the risk factors which are associated with the causation of breast cancer. The present review article helped to see other people's views and perspectives regarding Breast Cancer among female. It helped in identifying recent research and significant advances in this cancer research. It helped in knowing the other people working in related field. Review of related literature was done by means of a careful perusal of researches already done and write ups published or lectures delivered on issues directly or indirectly connected with breast cancer in female.
\end{abstract}

Key word: Breast cancer, female, cancer advancement, review.

\section{ABOUT AUTHORS:}

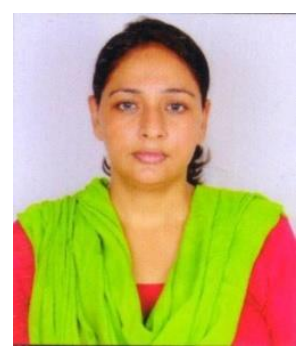

Author Ms. Navjot Kaur is Ph.D. Scholar at Himalayan University at Itanagar, Arunachal Pradesh, India. She is active researcher and has attended various Seminars and conferences.

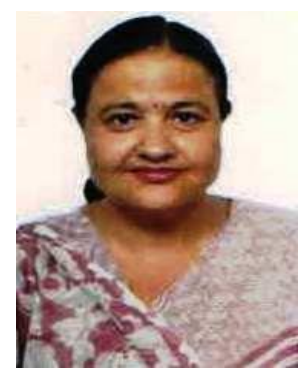

Author Dr. Ramesh Kumari is Principal at Mai Bhago College of Nursing, Tarn Taran, Punjab, India. She is Research Supervisor in Himalayan University, Itanagar. She has attended and organised Workshops, Seminars and Conferences. She has published various research articles in National and International Journals. 


\section{ARTICLES}

\section{INTRODUCTION:}

A careful review of the related literature on the problem similar or related to the one been investigated was done. It was done to get help in the planning of research. The study of related literature was done by locating, reading and evaluating reports of worldwide research. The reports of casual information and opinions that were found related were also explored.

\section{LITERATURE REVIEW:}

National Cancer Institute (2012) Breast cancer is "the cancer that forms in tissues of breast, usually the ducts (tubes that carry milk to the nipple) and lobules (glands that make milk). It can occur in male and female, male breast cancer is rare". Estimated new cases and deaths from breast cancer in the United States in 2012 are new cases 2, 26870 and deaths 39,510. A.D.A.M. Medical Encyclopedia (2012) Breast cancer is a cancer that starts in the tissues of breast. There are two main types of breast cancer; ductal carcinoma that starts in the tubes that carry milk from the breast to the nipple and lobular carcinoma that starts in the lobules that produce milk. Breast cancer may be invasive or non-invasive. Invasive means it has spread from the milk ducts to other tissues and noninvasive means it has not yet invaded the other breast tissues. Balentine R. J, et al (2012) Patients with breast cancer has many treatment options. Most treatments are adjusted specifically to the type of cancer and the staging group. Most women with breast cancer will require surgery. The surgical therapies for breast cancer includes breast conserving surgery, lumpectomy, and mastectomy. The other measures include radiation therapy, chemotherapy and hormone therapy. Stanley MC (2011) Breast cancer like other cancers occurs, because of an interaction between the environment and a defective gene. Normal cells divide as many times as needed and stop. They attach to other cells and stay in place in tissues. Cells become cancerous when mutations destroy their ability to stop dividing, to attach to other cells and to stay where they belong. Breast cancer occurs through various stages. Breast cancer staging using the TNM system is based on the size of the tumor, whether or not the tumor has spread to lymph nodes in the armpits, whether the tumor has metastasized.

Shaheen G, et al (2011) the prevalence of breast cancer was evaluated. For this purpose, data was recorded from Bahawalpur Institute of Nuclear Medicines and Oncology (BINO). The results showed that prevalence of breast cancer during the year 2006, 2007, and 2008 was in increasing order. Data recorded on age of the patient at diagnosis, their residential areas, types of CA breast, stage of the disease and involved breast revealed that there is a peak of CA breast in the age group of 30-50 years and the patients visited BINO for diagnosis and treatment were mostly from Bahawalpur district followed by Bahawalnagar, Rahim Yar Khan and Multan etc. The commonest type of breast cancer recorded among the patients treated during 2006, 2007 and 2008 at BINO was infiltrating Ductal Cell Carcinoma. The patients were mostly diagnosed at II and III stage of breast cancer and most of the patients had carcinoma in their right breast.

Stanley P.L.Leong, et al (2010) The peak age for breast cancer is between 40 and 50 years in the Asian countries, whereas the peak age in the Western countries is between 60 to 70 years. Although the incidence of breast cancer in India is lower than that in western countries, the mortality rates are disproportionately higher. Thus, breast 
cancer remains the single largest cause for cancer deaths in Indian women. Globally it accounts for $15 \%$ of all cancer deaths in women, killing some 471.2 women per 1, 00000 annually. The 5-year survival rate of breast cancer patients reported at Bangalore's population based cancer registry was $43.2 \%$. Breast cancer affects one in eight women during their lives. It is more common than the other types of cancers in women. According to the present statistics it has to be controlled. As we know that there are various types of cancer, the prevalence of breast cancer is more in India as well as Punjab too. The chances of getting breast cancer increases as the women get older. The Times of India (2012) the crude breast cancer cases in urban India women is 25-30 and the age adjusted rate is 30-35 new cases per 1,00,000 women per year. Breast cancer is increasing - the average increase over a 30 year period in Mumbai was 11 percent per decade. Breast cancer is increasing both in young (11 percent per decade) and old women (16 percent per decade). There are an estimated 1,00,000- 1,25,000 new breast cancer cases in India every year. The number of breast cancer cases in India is estimated to double by 2025 . The age adjusted incidence of cervix cancer in urban India is 15-20 new cases per 1,00,000 women per year. Sandhu $\mathrm{K}$ (2012) The Tribune, Chandigarh India in a report stated that Malwa zone is facing the threat of cancer, if one were to go by the reports compiled by Roko Cancer, a United Kingdom based organization which is conducting mammography tests. In the whole Punjab, Roko cancer has organized as many as 700 cancer detection camps and checked about 1,00000 women, out of which 16,000 tests of mammography have been conducted on women during the past five years. At least, 950 women have been found suffering from breast cancer with another 2000 suspected cases. Ferlay J (2010) the incidence of breast cancer is rising in India and is now the second most commonly diagnosed in women. It is estimated that in 2008 there were 115251 new cases of breast cancer with an age standardized incidence rate of 22.9 per 100000 . It is estimated that by 2030 , the number of new cases of breast cancer in India will reach just under 2, 00000 per year. International Agency for Research on Cancer (2010) Incidence of the breast cancer is increasing in the developed and developing countries. There were 1.7 million breast cancer cases diagnosed worldwide and 4, 65,000 women died due to breast cancer in 2007 . In India the incidence rate are 19.1 per 1, 00000 population and death rate 10.4 per 1, 00000 population.

Boyle P and Howell A (2010) Breast cancer is the commonest form of cancer in women worldwide; there were an estimated 1.4 million cases worldwide in 2008 and there is no part of the world where breast cancer is now a rare form of cancer. In all major regions of the world, breast cancer is the commonest, or second commonest, cancer in women. Focus on breast cancer up until now has almost entirely been on the situation in high-income, westernized, industrialized countries. However, there is a world out there out with North America and Western Europe where cancer is a major and growing problem facing public health. With the growth and ageing of the world's population, notable increases in life expectancy in people of lower-income levels in many countries and the increased tendency to adopt a westernized lifestyle, cancer is a rapidly growing global problem and not one that the majority of the world is ready to cope with. American Cancer Society (2009) provided the statistics regarding the risk of developing breast cancer among women in the next 10 years, as follows: By age 20, 1 out of 1,760 ; by age 30, 1 out of 229; by age 40, 1 out of 69 ; by age 50, 1 out of 27; by age 60, 1 out of 29; by age 70, 1 
out of 27; lifetime, 1 out of 8. Park K (2007) Breast cancer is one of the commonest causes of death in many developed countries in the middle aged women and is becoming frequent in developing countries as well. Breast cancer causes 3,76,000 deaths a year worldwide, about 9, 00,000 women are diagnosed every year with the diseases. More than half of these cases are in industrialized countries- about 2, 20,000 in Europe and about 1 , 80,000 in North America.

International Association of Cancer Research (2005) projected that there would be, 50,000 cases of breast cancer in India by 2015, a 3\% increase per year. India reports roughly 1, 00000 new cases annually. There are also significant regional variations in incidence rates. The overall rate is now estimated at 80 new cases per 100000 population per year. But in Delhi, that rate is 146 per 100000 . By contrast, the national rate was 23.5 in 1990 . The studies have shown that the education level directly affects the knowledge regarding breast cancer. The rural population is having less awareness about the breast cancer. So these people need to improve their knowledge. WHO Global Burden of Disease (2004) Breast cancer is the most common cancer in women worldwide, comprising $16 \%$ of all female cancers. It is estimated that 000519 women died on 2004 due to breast cancer, and although breast cancer is thought to be a disease of the developed world, a majority $69 \%$ of all breast cancer deaths occur in developing countries. Incidence rates vary greatly worldwide, with age standardized rates as high as 99.4 per 100 000 in North America. Eastern Europe, South America, Southern Africa, and western Asia have moderate incidence rates, but these are increasing. The lowest incidence rates are found in most African countries but here breast cancer incidence rates are also increasing. Breast cancer survival rates vary greatly worldwide, ranging from $80 \%$ or over in North America, Sweden and Japan to around $60 \%$ in middle-income countries and below $40 \%$ in lowincome countries. The low survival rates in less developed countries can be explained mainly by the lack of early detection programmes, resulting in a high proportion of women presenting with last-stage disease, as well as by the lack of adequate diagnosis and treatment facilities. With the help of this research study, the researcher want to know the present level of knowledge of the selected area group regarding all these risk factors, its prevention and to enhance their knowledge by giving structured teaching programme to the rural people. The researcher while working in the clinical area observed that numerous cases were admitted with breast cancer had lack of knowledge about breast cancer and the measures taken to prevent it. Also there is paucity of research studies done in this field. By improving the knowledge of women about breast cancer and its preventions, the researcher would help in reducing the mortality and morbidity to some extent among women. This led the researcher to undertake the present study.

\section{CONCLUSIONS:}

The related literature studied by investigator shows in clear terms that the many studies have been undertaken on various aspects of breast cancer in women. It helped in identifying recent research and significant advances in this cancer research. It helped in knowing the other people working in related field. Review of related literature was done by means of a careful perusal of researches already done and write ups published or lectures delivered on issues directly or indirectly connected with breast cancer in female while going through those studies researcher 


\section{ARTICLES}

got advantage of the knowledge. It was found that number of study highlighted the Breast cancer in woman and various cause of breast cancer; rather a combination of hormonal, genetic and possibly environmental events may contribute to its development.

\section{REFERENCES}

1. Asif. Breast cancer: statistics of breast cancer, breast cancer study [document on the internet]. Surgical blog; 2011 [cited 2011 Sep 4]. Available from: http://www.surgical-blog.com/breast-cancer-statistics-of-breastcancer-breast-cancer-study/ surgical blog.

2. Abdul Hadi M, Hassali MA, Shafie AA, Awaisu A. Knowledge and perception of breast cancer among women of various ethnic groups in the state of Penang: a cross-sectional

3. A.D.A.M. medical encyclopedia [Internet]. Breast cancer: A.D.A.M, Inc.; 2012 [cited 2012 Dec 26]. Available from: http://www.ncbi.nlm.nih.gov/pubmedhealth.

4. Ahuja S, Chakarbarti N, To determine the level of knowledge regarding breast cancer and to increase awareness about breast cancer screening practices among a group of women in tertiary care hospitals in Mumbai; India .the internet journal of public health. (Abstract).2010; vol, 1, no.1, ISSN; 2155-6733 Available from - http \lwww.ispub.com| the internet journal the internet journal of public health. National Cancer Institute .Breast cancer statistics. http://www.cancer.gov.

5. Beck T.C, Polit F.D. Nursing Research. 9th ed. London: Lippincott Williams and welkins; 2004.

6. Daily News and Analysis. Breast cancer cases in India double by 2015: Experts. New Delhi: Health report. 19 Oct 2011.

7. Ferlay J. Risk Factors for Breast Cancer in India: an INDOX Case-Control Study. Indox cancer research network, 2010. Available from: http://www.indox.org.uk.

8. Kanaga KC, Nithiya J, Shatirah MF. Awareness of breast cancer and screening procedures among Malaysian women. Asian Pac J Cancer Prev [abstract]. 2011 [cited 5 Mar 2011]; 12(8):1965-7. Available from:http://www.ncbi.nlm.nih.gov/pubmed. survey. Med Princ Pract [abstract]. 2010 [cited 9 Dec 2009]; 19(1):61-7. Available from: http://www.ncbi.nlm.nih.gov/pubmed.

9. Leong P.L.S. Is breast cancer the same disease in Asian and western countries. World J Surg. 2010 Jul [cited 2002 Aug 12]; 102(6). Available from: http:/www.ncbi.nlm.nih.gov./pmc/articles.

10. Martins E, Junior R, Curado M, Freitas Maya Aires N, Silva C, Oliveira J. Prevalence of breast cancer in the city of Goiânia, Goiás, Brazil, between 1988 and 2002. Sao Paulo Med. J. [abstract]. 2010 [cited 2 May 2011]; 129(5). Available from: http://dx.doi.org/10.

11. Mc Stanley. Breast cancer. Encyclopedia. http://en.wikipedia.org/wiki/Breast cancer.

12. Oluwatosin $\mathrm{OA}$, Oladepo $\mathrm{O}$. Knowledge of breast cancer and its early detection measures among rural women in Akinyele Nigeria. BMC Cancer [abstract]. 2006 [cited 26 Nov 2006]; 6 (1) 271. Available from: http://www.ncbi.nlm.nih.gov/pubmed.

13. Park K. Preventive and Social medicine. 19th ed. New Delhi: Jaypee brothers medical 


\section{ARTICLES}

publishers; 2007.

14. Parkin DM, Fernández LM. Use of statistics to assess the global burden of breast cancer. Breast J. [abstract]. 2006 [cited 6 Jan 2006]; 12 Suppl 1:S70-80. Available from: http://www.ncbi.nlm.nih.gov/pubmed.

15. Pınar E Dundar, Dilek Ozmen, Beyhan Ozturk, Gokçe Haspolat, Filiz Akyıldız, Sumeyra Çoban et al. The knowledge and attitudes of breast self-examination and mammography in a group of women in a rural area in western Turkey. BMC Cancer [abstract]. 2006 [cited 24 Feb 2006]; 6-43. Available from: http://www.biomedcentral.com.

16. Rudat V, Brune-Erbe I, Noureldin A, Bushnag Z, Almuraikhi N, Altuwaijri S. Epidemiology of breast cancer patients at a tertiary care center in the Eastern Province of Saudi Arabia. Gulf J Oncolog. [serial online]. 2012 [cited 5 Jan 2012]; 1(11):45-9. Available from: http://www.ncbi.nlm.nih.gov/pubmed.

17. Ramakant P, Agarwal G, Breast Cancer Care in India: The Current Scenario and the Challenges for the Future. Breast Care (Basel) [Internet]. 2008 March [cited 2008 Feb 22] 3(1): 21-27. Available from http://www.ncbi.nlm.nih.gov/pmc/articles/PMC

18. Sandhu K. Women in Malwa facing threat of breast cancer: study. The Tribune Chandigarh Bathinda Edition. 2012 Feb 18; Sect. A: 2 (col. 4).

19. Sim HL, Seah M, Tan SM. Breast cancer knowledge and screening practices: a survey of 1,000 Asian women. Singapore Med J. [abstract]. 2009 [cited 10 Feb 2009]; 50(2):132-8. Available from: http://www.ncbi.nlm.nih.gov/pubmed.

20. Somdatta $\mathrm{P}$, Baridalyne N. Awareness of breast cancer in women of an urban resettlement colony. Indian J Cancer [abstract]. 2008 [cited 4 Oct 2009]; 45(4):149-53. Available from: http://www.ncbi.nlm.nih.gov/pubmed. 